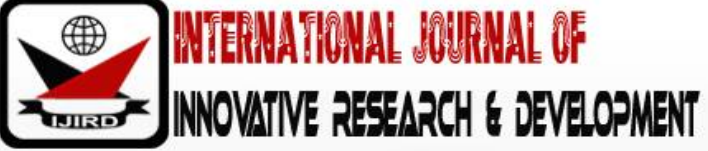

ISSN 2278 - 0211 (Online)

\section{Pattern of Government Recurrent Expenditure and Economic Growth in Nigeria}

\author{
Chukwu Agwu Ejem \\ Lecturer, Abia State Polytechnic, Abia, State, Nigeria \\ Dr. Udochukwu Godfrey Ogbonna \\ Executive Chairman, Abia State Internal Revenue Service, Nigeria
}

\begin{abstract}
:
The main objective of this study is to examine the effects of recurrent expenditure components; namely, Administration, Social and Community Services, Economic Services and Transfers, on economic growth in Nigeria. The VAR methodological framework is employed while the empirical data cover from 1981 to 2016. The results show that while GDP responded positively to a one standard deviation shock to recurrent expenditure on administration, it responded negatively to a one standard deviation shock to recurrent expenditure on both social community services and transfer. GDP has almost zero response to a one standard deviation shock to recurrent expenditure on economic services. The results further show that most of the GDP shock are due to own effect. Compared to other components of recurrent expenditure, the relative contribution of recurrent expenditure on transfer to GDP innovation is highest in the second period while the relative contribution of recurrent expenditure on administration is highest in the third and fourth periods. However, the Granger Causality test shows that recurrent expenditure components none has a causal impact on GDP both individually and collectively. Therefore, the Keynesian view that public expenditure is a veritable fiscal tool for promoting and enhancing economic growth is not supported. The policy implication of our findings is that Federal government can only achieve the desired growth in economic activities using fiscal policy if the recurrent expenditure component of public expenditure is reduced. Further, the proportion of recurrent expenditure that is allocated to economic services should be increased while the proportion that is allocated to bot social community services and transfer should be decreased.
\end{abstract}

Keywords: Economic growth, government recurrent expenditure, VAR

\section{Introduction}

Deciding the pattern and growth of public expenditure has been the concern of researchers and theorists over several decades. Historically, public expenditure could be rightly argued to be continuously increasing overtime in almost every country. The concept of public expenditure is used to refer to the expenses, which the government incurs for its own maintenance and also for the society and economy as a whole (Bhatia, 2004; Edame, 2001).Government spending has accounted for a rising proportion of national income in the twentieth century. This applies to most countries regardless of their level of economic development (Lindaver \& Valenchik, 1992). Wagner (1963) on the basis of empirical findings came up with a view that there was a long-run tendency for state activities to grow relative to the growth in national income.

According to Wagner (1963), many public outputs are income elastic so that as development progresses and per capita income increases, demand for them increases by a larger percentage. Also, as argued by Ezirim and Ofurum (2003), the size of a government and in some cases of the country has been measured in terms of the total spending of the particular government or country. Among them are Wagner's law of increasing state activities, Wiseman-peacock hypothesis, critical limit hypothesis, Levianthan hypothesis, differential productivity hypothesis and the relative price hypothesis.

A critical look at these theories will reveal a plethora of factors that are said to determine the growth of public expenditure. Some of these factors are inflation, total revenue of the country, total debt over-hang and debt service or burden ratio, per capital income or output of the country, and strategic transfers from Federal government to the state government (Ezirim, Moughalu \& Elike, 2008). Others include population growth, urbanization effect, and taxation.

In Nigeria, government expenditure can be majorly categorized into capital and recurrent expenditure. Recurrent is referred to as government expenses on administration wages, salaries, interest on loans maintenance etc. whereas expenses on capital projects like roads, airports, health, education, telecommunication and electricity generation etc., are referred to as capital expenditure (Okoro, 2013). Furthermore, by providing new opportunities and expanding the capabilities of the masses, government spending plays an important role in ensuring sustainable economic growth (Josaphat \&Oliver, 2000). 
Further, despite the huge revenue from crude oil export, Nigeria as a nation is not rightly placed in terms of human development (poor access to basic social infrastructure, portable water, electricity, health, education, high level of unemployment, high level of insecurity etc.). Previous government of all tiers allocated huge funds to various projects such as roads, industries and other growth like and developmental ventures yet, get dilapidated sooner or later they were provided.

The above situation casts doubt on whether government expenditure is in manner it can have impact on economic growth in Nigeria. Presently, the Buhari administration has come up with the change mantra geared at fostering economic growth and development, which kicked as the chip of the old block. It must be noted that this was equally the case with VISION 2010, which targeted elimination of illiteracy, which was at 52\% and increasing the life expectancy level of citizen, which was at 54 years. Paradoxically, apart from recorded dwindling growth, this measure ended up among other things, achieving increased illiteracy rate at $65 \%$ and reducing life expectancy to 48 years. And other related cases.Under this scenario, one wonders whether government expenditure has been consistent with the recorded volume of oil revenue, or enough has been spent but not judiciously as to engender economic growth.

The linkage between public expenditure and economic growth has attracted serious interest on the part of researchers both at the theoretical and empirical level. This interest is as a result of the role of public expenditure on infrastructures such as roads, ports, communication systems, public research spending, provision of basic educational and health services on the economic potential of any country (Irmen \& Kuehnel, 2008; Nuruden \& Usman, 2010). According to Maku (2009), the general view is that public expenditure either recurrent or capital on social or economic infrastructure can be growth-enhancing although the financing of such expenditure toprovide essential infrastructural facilities-including transport, electricity, telecommunications, water and sanitation, waste disposal, education and health can be growthretarding. Also, Afonso and Furceri (2007) and Minea (2008) suggested that public spending on infrastructural facilities is widely seen as having an important role in affecting economic growth.

However, there are two opposing views on this issue. The Keynesian approach argues that public spending is an important policy tool to be used to ensure a reasonable level of economic activities; correct short-term cyclical fluctuations in aggregate expenditure; and secure an increase in productive investment, thus providing a socially optimal direction for growth and development (Jhingan, 2004). The opposite view is that excessive government intervention in economic life affects growth performance in a negative way for two reasons: first, because operations are often conducted inefficiently, hence they reduce the overall productivity of the economic system; second because excessive government spending distorts economic incentives and results in sub-optimal economic decisions (Vaish, 2002).

From the forgoing, the questions that is begging for answers are: What is the direction and extent of the effect of public recurrent expenditure on economic growth? (2) What is the relative impact of each public recurrent expenditure components on economic growth.

This study attempts to provide insightful answers to these questions by investigating the extent to which pattern of government recurrent expenditure (Administration, Social and Community Services, Economic Services, and Transfers) affect the level of economic growth in Nigeria within the VAR framework using data from 1981 to 2016.

The remainder of this study has the following structure: The next section reviews the conceptual, theoretical and empirical literature. Section 3 describes the data and methodology. Section 4 contains empirical analysis and results. The study is concluded in section 5 .

\section{Literature Review}

\subsection{Theoretical Foundation}

\subsubsection{Wagner's Law of Increasing State Activities}

Adolf Wagner in his well celebrated book, Grundlegung der Politischen Okonomie, published in 1963 formulated a law of increasing state activities. He asserted that there is a long run propensity for the scope of government to increase with higher levels of economic development. Before Wagner made his observations, the prevailing views was the notion that as a country grows richer, government activities would have a tendency to decline (Henrekson, 1993). Bird (1971) concurred with Wagner's law stating that 'the activities of government are an increasing function of the changing structure of the economy'. Whether the state decides to combat or to support private sector activity such as private monopolies, with the growth of this sector, it is plausible to assume that public sector activity will increase. It is conventional however, to use per capita income as an index of development but this is not the only index of development nor is it the only compatible interpretation of the law but it continues to be used by most economists (Bird, 1971; Goffman, 1968; Gupta, 1967; Michas, 1975; Musgrave, 1969). Government expenditure is probably the most significant and practical measure of the state's activity.

\subsubsection{Wiseman-Peacock Hypothesis}

Peacock and Wiseman (1979), this theory also looked at increasing public expenditure from the socio-political perspective. Government expenditure will increase as income increases but because the leaders want re-election into political offices, so more infrastructure must be provided in order to convince the electorate that their interest are being catered for by the people they voted into power. However, the citizens of the country are less willing to pay tax. The resistance to pay tax by the people will make the state to have low revenue hence the cost of providing more facilities is born by the government, making government expenditure to increase rapidly. 


\subsubsection{Keynesian Public Expenditure- Economic Growth Theory}

Keynesian public expenditure- economic growth theory has attracted a vast array of empirical investigation by economists especially from academic setting over time. Keynesians" in other hand postulates a function with the orientation that runs from government increasing undertakings to economic improvements. These expenditures are considered as normal goods in society's stance with income elasticity of demand greater than one. Keynesian's stance evolved at the hill of the Great depression of late 1930s. This advocating for government involvement in the economic managements brought about, a tremendous evolution in the field of economic. The periods witness a considerable growth on sensitive economic indicators such as investments, employment creation, and general demands whereof government spending (Musgrave and Musgrave, 1989).

\subsection{Empirical Review}

Severalempirical works have been carried out on government expenditure and economic growth and there exists some contradictions and corroborations, hence no consistent evidence for a significance and functional relationship between government expenditure and economic growth. Some tilted toward positive and significant relationship while others to either positive and insignificant or negative and significant. It was discovered that scanty work was done on the pattern of government expenditure and economic growth.

Miftahu and Rosni (2017) investigated public sector spending and economic growth in Nigeria: In search of a stable relationship employed ARDL model. The model revealed the existence of positive and significant relationship between public spending and economic growth in Nigeria. From the findings, it is evident that government expenditure is considered to be highly important in creating opportunities and widening the productive base at which developing countries can grow, Nigeria is inclusive.

Sevitenyi (2012) analyzed the relationship and the direction of causality between public spending and economic growth in Nigeria by adopting a Granger causality test using annual time series data from 1961 to 2009. Aggregate government expenditure is disaggregated into recurrent expenditure, capital expenditure, administration, social and community services, economic services and transfers. Finding revealed that there is a unidirectional causality running from aggregate public spending to economic growth, which supports the Keynesian hypothesis. Moreover, at the disaggregate level, results show that all the variables except recurrent expenditure cause economic growth, implying that government expenditure promotes growth in Nigeria. In general, this result does not empirically support the existence of Wagner's law both at the aggregate and disaggregate level.

Taiwo and Abayomi (2012) examined government expenditure and economic development: Empirical evidence from Nigeria over the last decades (1970-2008) using econometrics model with OLS techniques. They found that there is a positive relationship between real GDP as against the recurrent and capital expenditure.

Ogundipe and Oluwatobi (2012) in their paper investigated the effect of government expenditure on growth rate in Nigeria using the Johansen co-integration analysis. Evidences from the analysis spanning from 1970-2009 shows that the components of total government expenditure induced a negative (except spending on education and health) and insignificant in explaining the trend of economic growth.

Edame and Akpan (2013) examined empirically the structure and growth of federal government expenditure in Nigeria in the time series data for the period of 1970 to 2009. The OLS regression technique was employed as the main method of data estimation. The result obtained revealed that factors such as fiscal deficit, GDP, Government revenue and debt servicing are some of the factors causing growth in the government expenditure in Nigeria for the reference period. Danladi, Akomolafe and Anyadiegwu (2015) examined government expenditure and its implication for economic growth in Nigeria. The ARDL methodology was employed to examine the relationship between the variables. From the analysis and findings, government spending significantly and positively explained the economic growth of the country.In comparing the results of the total government expenditure in the capital and recurrent expenditure, the result shows that they are positively related to economic growth howeverthe recurrent component of expenditure significantly explained more. This study attests to the Keynesian model (1936) of government intervention in the economy.

Oziengbe (2013) investigated the relative impacts of federal capital and recurrent expenditures on Nigeria's economy (1980-2011). The study employed ECM model and revealed that total government expenditure had significant positive effect on Nigeria's economy in the period covered. It confirms postulation of Keynesian theory and implies that Nigeria economy at its current stage of development owes much to government spending.

Akanbi (2014) in his work Government expenditure in Nigeria: Determinants and the trends employed a public choice framework and the model is estimated in the time series data from 1974 to 2012, using the Johansen estimation techniques. The results show that capital and recurrent expenditure are resilient to shocks in total government spending and, similarly, total government expenditure is found to be resilient to shocks in capital and recurrent spending. The increased per capita income was found to be in support of the Wagner's law in total and capital expenditure specifications, but this was refuted by the recurrent expenditure specification.

Ditimi, Nwosa, and Ajisafe (2011) investigated the relationship between the components of government expenditure (that is, education, agriculture, health and transport and telecommunication) on economic growth in Nigeria for the period spanning 1970 to 2010. The results of the long run and short run regression estimates confirmed that expenditure on agriculture was the most significant component of government expenditure which impacted on economic growth.

Chude and Chude (2013) investigated the effect of public expenditure in education on economic growth in Nigeria over a period from 1977 to 2012, with particular focus on disaggregated and sectoral expenditure analysis. The study used 
ECM and the results indicated that total expenditure on education is highly and statistically significant and have positive relationship on economic growth in Nigeria in long run.

Appah and Ateboh-Briggs (2013) investigated the co integration patterns of public expenditure and growth in Nigeria for the period 1961-2010 employed VECM and other Diagnostic tests. The results from econometric analysis revealed that pattern of public expenditure on administration, social community series, economic services and transfers affects the economic growth of Nigeria.

Okanta (2009) in a study, the impact of public education expenditure on Economic growth in Nigeria (19902008), using simple, bivariate regressions shows that public education expenditures are statistically significant in affecting real GPD and real per capita in Nigeria. Also, that expenditure is not statistically significant in influencing economic growth using multivariate regression.

Adewara and Oloni (2012) in composition of public Expenditure and Economic growth in Nigeria examined the relationship between public expenditure compositions from 1960-2008 on economic growth using the Vector Autoregressive Model (VAR). The study exposes that expenditure on education has failed to enhance economic growth due to the high rate of rent seeking in the country and high rate of unemployment

\section{Methodology}

\subsection{Data}

The empirical data consist of annual time series observations from 1981 to 2016 . The study variables are gross domestic product(A proxy for economic growth), recurrent expenditure on administration, social and community services, economic services and transfers. The statistical bulletin of the Central Bank of Nigeria 2016 version is the source of data collection. While the empirical analysis is done in EViews 9, all variables are log-transformed for reliable empirical results.

\subsection{Empirical Framework}

The main empirical framework for this study is the Vector Autoregressive model (VAR). The functional specification of the relationship between recurrent expenditure patterns and economic growth is given by:

$G D P=f($ Pattern of Government of Expenditure $)$

(1)

$G D P=f($ Admin, Comserv, Ecoserv, Trans $)$

(2)

The VAR (1) representation of the above functional model is given by: $G D P_{t}=\beta_{01}+\beta_{11} G P_{t-1}+\beta_{21}$ ADMIN $_{t-1}+\beta_{31} \operatorname{COMSERV~}_{t-1}+\beta_{41} \operatorname{ECOSERV~}_{t-1}+\beta_{51} \operatorname{TRANS}_{t-1}+u_{1 t}$ (3)

$\operatorname{ADMIN}_{t}=\beta_{02}+\beta_{12} \operatorname{GDP}_{t-1}+\beta_{22} \operatorname{ADMIN}_{t-1}+\beta_{32} \operatorname{COMSERV~}_{t-1}+\beta_{42} \operatorname{ECOSERV~}_{t-1}+\beta_{52} \operatorname{TRANS}_{t-1}+u_{2 t}$ (4)

$\operatorname{COMSERV~}_{t}=\beta_{03}+\beta_{13} \operatorname{GDP}_{t-1}+\beta_{23}$ ADMIN $_{t-1}+\beta_{33} \operatorname{COMSERV~}_{t-1}+\beta_{43} \operatorname{ECOSERV~}_{t-1}+\beta_{53}$ TRANS $_{t-1}+u_{3 t}$ (5)

$\operatorname{ECOSERV~}_{t}=\beta_{04}+\beta_{14} \operatorname{GDP}_{t-1}+\beta_{24}$ ADMIN $_{t-1}+\beta_{34} \operatorname{COMSERV~}_{t-1}+\beta_{44} \operatorname{ECOSERV}_{t-1}+\beta_{54} \operatorname{TRANS}_{t-1}+u_{4 t}$ (6)

TRANS $_{t}=\beta_{05}+\beta_{15} \operatorname{GDP}_{t-1}+\beta_{25} \operatorname{ADMIN}_{t-1}+\beta_{35} \operatorname{COMSERV~}_{t-1}+\beta_{45} \operatorname{ECOSERV~}_{t-1}+\beta_{55} \operatorname{TRANS}_{t-1}+u_{1 t}$ (7)

Where;

GDP $=$ Gross Domestic Product

Admin = Recurrent expenditure on government such as general administration, defense, internal security and national assembly.

Comserv $=$ Recurrent expenditure on provision of social and community services such as education, health, and other social and community services

Ecoserv $=$ Recurrent expenditure on provision of economic services such as agriculture, construction, transportation \& communication and other economic services.

Trans =Recurrent expenditure on public debt servicing, pension and gratuities, contingencies/ subventions .

\section{Empirical Analysis}

\subsection{Sta tionarity Test}

Table 4.1 presents the ADF unit root test results for GDP, ADMIN, COMSERV, ECOSERV and TRANS. We report only the first difference results because none of the variables is stationary at level data. The Table shows that all variables are stationary at first difference. 


\begin{tabular}{|c|c|c|c|c|c|}
\hline \multirow{2}{*}{ Variables } & Lag & ADF Test Statistic & \multicolumn{2}{|c|}{ Critical Values } & \multirow{2}{*}{ Remarks } \\
\cline { 2 - 5 } & SCI & 1st difference & $\mathbf{1 \%}$ & $\mathbf{5 \%}$ & \\
\hline LOGGDP & 9 & -5.300117 & -3.639407 & -2.951125 & Stationary \\
\hline LOGADMIN & 5 & -7.256352 & -3.639407 & -2.951125 & Stationary \\
\hline LOGCOMSERV & 9 & -7.083636 & -3.639407 & -2.951125 & Stationary \\
\hline LOGECOSERV & 9 & -7.163360 & -3.639407 & -2.951125 & Stationary \\
\hline LOGTRANS & 9 & -8.174344 & -3.661661 & -2.960411 & Stationary \\
\hline
\end{tabular}

Table 1: Augmented Dickey-Fuller Unit Root Test

\subsection{VAR Analysis and Results}

Table 2 show the model selection results based on three information criteria; Akaike information criterion (AIC), Schwarz information criterion (SC) and Hannan-Quinn information criterion (HQ). As we can see, all the criteria select a VAR with lag 1 as the optimum model for the relationship between recurrent expenditure components and economic growth in Nigeria.

\begin{tabular}{|c|c|c|c|}
\hline Lag & AIC & SC & HQ \\
\hline 0 & 9.438190 & 9.662655 & 9.514739 \\
\hline 1 & $5.188968^{*}$ & $6.535757^{*}$ & $5.648262^{*}$ \\
\hline 2 & 5.441877 & 7.910990 & 6.283915 \\
\hline
\end{tabular}

Table 2: Model Selection Results

Table 3 shows the estimated VAR (1) results for the relationship between pattern of recurrent expenditure and economic growth in Nigeria. However, since it is well documented that the reduced form VAR is difficult to interpret due it's a theoretical nature, we proceed to check whether the estimated model is well specified and stable.

Table 1 shows the LM test for serial correlation. Figure 1 shows the VAR inverted roots in relation to unit circle which determines whether the estimated VAR coefficients are stable, a precondition for examining the economic significance of the VAR results. As we can see, while the LM test in Table 1 is insignificant, the VAR inverted roots in Figure 1 all are inside the unit circle. These indicate that our estimated VAR(1) is both well specified and stable, hence, can be relied upon for policy analysis and prediction.

\begin{tabular}{|c|c|c|c|c|c|}
\hline Variable & LOGGDP & LOGADMIN & LOGCOMSERV & LOGECOSERV & LOGTRANS \\
\hline & 0.632158 & 0.248734 & 0.383694 & 0.136685 & 0.009163 \\
& $(0.27935)$ & $(0.12063)$ & $(0.15240)$ & $(0.22238)$ & $(0.10408)$ \\
LOGGDP(-1) & {$[2.26298]$} & {$[2.06199]$} & {$[2.51773]$} & {$[0.61463]$} & {$[0.08803]$} \\
\hline & 1.195602 & 0.781397 & 0.895633 & -0.126100 & 0.029542 \\
& $(0.71986)$ & $(0.31085)$ & $(0.39272)$ & $(0.57307)$ & $(0.26822)$ \\
LOGADMIN(-1) & {$[1.66088]$} & {$[2.51374]$} & {$[2.28061]$} & {$[-0.22004]$} & {$[0.11014]$} \\
\hline & -0.266056 & -0.385632 & -0.396529 & -0.196615 & 0.019927 \\
& $(0.37456)$ & $(0.16174)$ & $(0.20434)$ & $(0.29818)$ & $(0.13956)$ \\
LOGCOMSERV(-1) & {$[-0.71031]$} & {$[-2.38422]$} & {$[-1.94053]$} & {$[-0.65938]$} & {$[0.14279]$} \\
\hline & -0.192765 & 0.166055 & 0.332362 & 0.764257 & 0.168644 \\
& $(0.36780)$ & $(0.15882)$ & $(0.20065)$ & $(0.29280)$ & $(0.13704)$ \\
LOGECOSERV(-1) & {$[-0.52410]$} & {$[1.04553]$} & {$[1.65642]$} & {$[2.61017]$} & {$[1.23061]$} \\
\hline & -0.572478 & 0.267404 & -0.123665 & 0.591791 & 0.682434 \\
& $(0.43255)$ & $(0.18678)$ & $(0.23598)$ & $(0.34435)$ & $(0.16117)$ \\
LOGTRANS(-1) & {$[-1.32349]$} & {$[1.43162]$} & {$[-0.52406]$} & {$[1.71858]$} & {$[4.23431]$} \\
\hline & 2.155857 & -1.371015 & -2.407998 & -1.808066 & 0.948087 \\
& $(1.41793)$ & $(0.61229)$ & $(0.77355)$ & $(1.12880)$ & $(0.52832)$ \\
& {$[1.52042]$} & {$[-2.23916]$} & {$[-3.11293]$} & {$[-1.60176]$} & {$[1.79454]$} \\
\hline Constant & 0.890278 & 0.984470 & 0.979169 & 0.959060 & 0.982664 \\
\hline R-squared & 0.871360 & 0.981793 & 0.975577 & 0.952001 & 0.979675 \\
\hline Adj. R-squared & 17.07170 & 3.183331 & 5.080889 & 10.81927 & 2.370042 \\
\hline Sum sq. resids & 0.767254 & 0.331316 & 0.418573 & 0.610801 & 0.285877 \\
\hline S.E. equation & 47.06084 & 367.6755 & 272.6256 & 135.8692 & 328.7682 \\
\hline F-statistic & & & &
\end{tabular}

Table 3: Estimated VAR (1) Results

\begin{tabular}{|c|c|c|}
\hline Lags & LM-Stat & Prob \\
\hline 1 & 19.82824 & 0.7558 \\
\hline 2 & 16.40460 & 0.9022 \\
\hline 3 & 29.05485 & 0.2616 \\
\hline
\end{tabular}

Table 4: LM Serial Correlation Test 


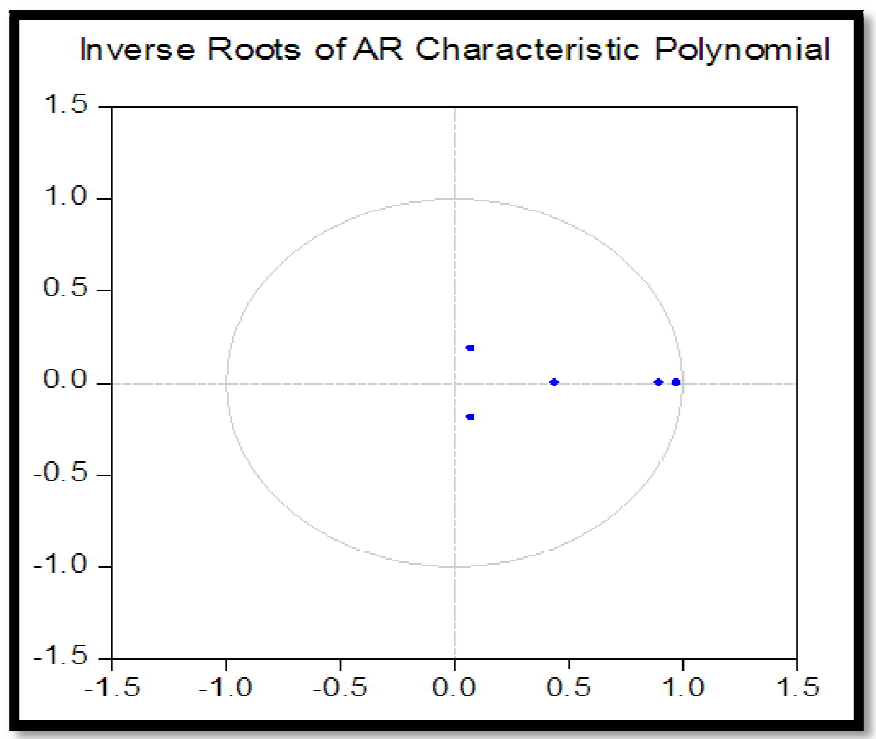

Figure 1: Inverse Root of AR Characteristics Polynomial

\subsection{Impulse Response Function}

Figures 4.2, 4.3, 4.4 and 4.5 show the response of GDP to a one standard deviation innovation in ADMIN, COMSERV, ECOSERV and TRANS respectively. As we can from these Figures, GDP responded positively to a one standard deviation shock to ADMIN while it responded negatively to a one standard deviation shock to both COMSERV and TRANS. The response of GDP to a shock to ECOSERV is almost zero. Thus, while the administration component of recurrent expenditure has positive effect on GDP, both transfer and community and social services components exert negatively effect on GDP. The effect of recurrent expenditure on economic services appears to be insignificant.

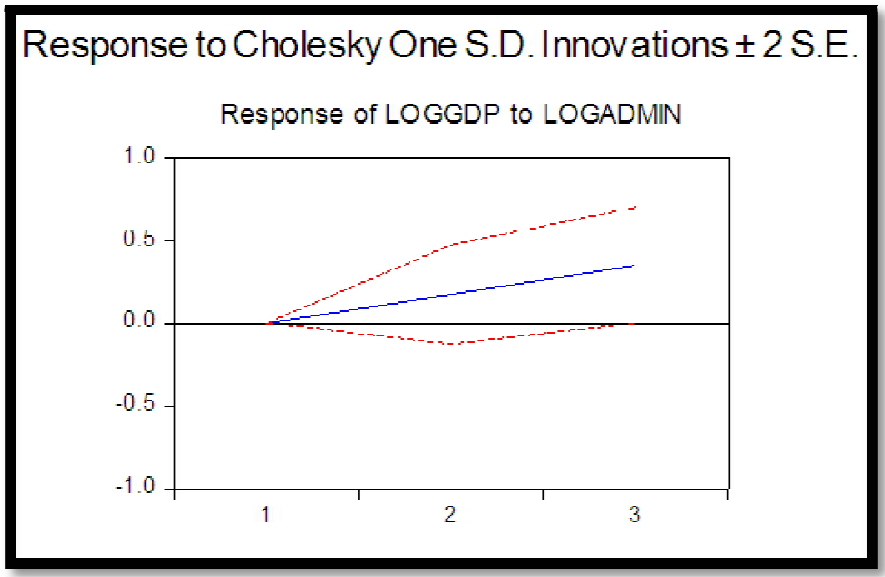

Figure 2: Response of GDP to Admin

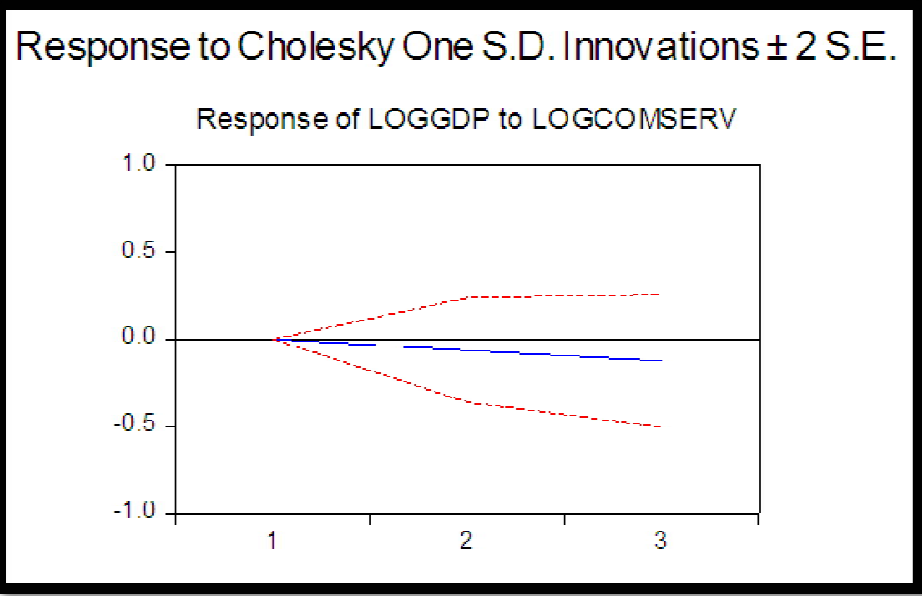

Figure 3: Response of GDP to COMSERV 
Response to Cholesky One S.D. Innovations \pm 2 S.E.

Response of LOGGDP to LOGECOSERV

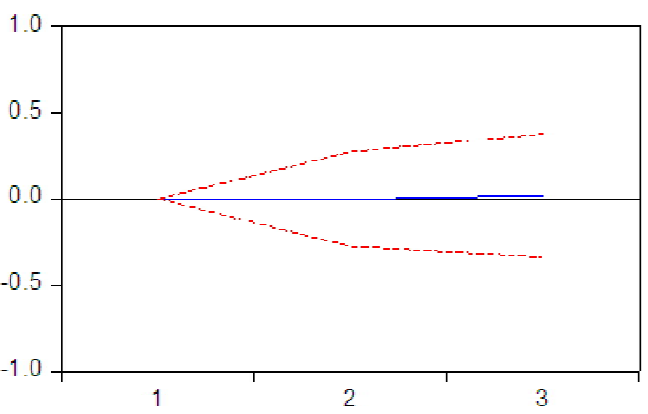

Figure 4: Response of GDP to ECOSERV

Response to Cholesky One S.D. Innovations \pm 2 S.E

Response of LOGGDP to LOGTRANS

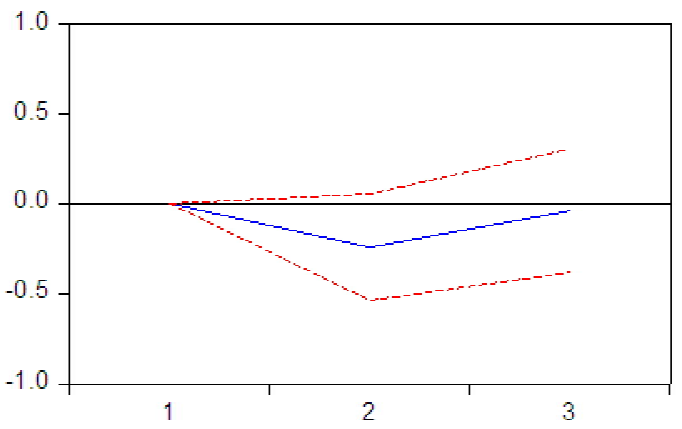

Figure 5: Response of GDP to TRANS

\subsection{Variance Decomposition}

Table 5 shows the relative contribution of ADMIN, COMSERV, ECOSERV and TRANS to the variance of GDP. This Table shows that most of the variance of GDP is due to own shock. However, among the recurrent expenditure components, TRANS has the highest contribution to GDP shock in the second period, while ADMIN has the highest contribution in the third and fourth periods. The proportion of variation in GDP that is due to the joint effect of recurrent expenditure components is approximately $9 \%$ in the first period (ADMN almost 3\%, COMSERV $0.38 \%$, ECOSERV almost zero and TRANS less than 6\%) and approximately 19\% (ADMIN 12.61\%, COMSERV 1.58\%, ECOSERV 0.03\% and TRANS $5.00 \%$ ) and 22\% (ADMIN 12.09\%, COMSERV 2.84\%, ECOSERV 0.14\% and TRANS 6.56\%) in the third and fourth periods respectively.

\begin{tabular}{|c|c|c|c|c|c|c|}
\hline Period & S.E. & LOGGDP & LOGADMIN & LOGCOMSERV & LOGECOSERV & LOGTRANS \\
\hline 1 & 0.745161 & 100.0000 & 0.000000 & 0.000000 & 0.000000 & 0.000000 \\
\hline 2 & 1.018808 & 90.91426 & 2.969151 & 0.382337 & 0.000156 & 5.734093 \\
\hline 3 & 1.105276 & 80.75753 & 12.61234 & 1.589835 & 0.037424 & 5.002867 \\
\hline 4 & 1.365944 & 78.35140 & 12.09703 & 2.840025 & 0.149035 & 6.562512 \\
\hline
\end{tabular}

Table 5: Variance Decomposition of GDP

\subsection{Granger Causality/ Block Exogeneity Tests}

Table 6 shows the results of Granger causality tests from ADMIN, COMSERV, ECOSERV and TRANS. As we can see, there is no evidence of causal relationships in our GDP equation, with the Chi-square statistic having a p-value that is higher than the conventional levels for all variables. Further, the four components of recurrent expenditure jointly have no causal impact on GDP as indicated by the variable "All" which is also insignificant ( $\mathrm{p}$-value $=0.1938$ ). 


\begin{tabular}{|c|c|c|c|}
\hline Excluded & Chi-sq & Df & Prob. \\
\hline LOGADMIN & 2.118912 & 2 & 0.3466 \\
\hline LOGCOMSERV & 0.503974 & 2 & 0.7773 \\
\hline LOGECOSERV & 0.020938 & 2 & 0.9896 \\
\hline LOGTRANS & 3.397680 & 2 & 0.1829 \\
\hline All & 11.14100 & 8 & 0.1938 \\
\hline
\end{tabular}

Table 6: Granger Causality Tests

\section{Summary and Conclusions}

The main objective of this study is to examine the effects of recurrent expenditure components; namely, Administration, Social and Community Services, Economic Services and Transfers, on economic growth in Nigeria. The VAR methodological framework is employed while the empirical data cover from 1981 to 2016.

The impulse response function shows that while GDP responded positively to a one standard deviation shock to recurrent expenditure on administration, it responded negatively to a one standard deviation shock to recurrent expenditure on both social community services and transfer. GDP has almost zero response to a one standard deviation shock to recurrent expenditure on economic services.

The variance decomposition of GDP shows that most of the GDP shock are due to own effect. Compared to other components of recurrent expenditure, the relative contribution of recurrent expenditure on transfer to GDP innovation is highest in the second period while the relative contribution of recurrent expenditure on administration is highest in the third and fourth periods. However, there is evidence from Granger Causality test that recurrent expenditure components none has a causal impact on GDP both individually and collectively. Therefore, the Keynesian view that public expenditure is a veritable fiscal tool for promoting and enhancing economic growth is not supported. The policy implication of our findings is that Federal government can only achieve the desired growth in economic activities using fiscal policy if the recurrent expenditure component of public expenditure is reduced. Further, the proportion of recurrent expenditure that is allocated to economic services should be increased while the proportion that is allocated to bot social community services and transfer should be decreased.

\section{References}

i. Adewara, S.O. \& Oloni, E.F. (2012). Composition of public expenditure and economic growth in Nigeria. Journal of Emerging Trends in Economics and Management Sciences (JETEMS), 3(4), 403-407.

ii. Afonso, A. \& Furceri, D. (2007). Government size, composition, volatility andeconomic growth. Department of Economics, School of Economics and Management, Technical University of Lisbon, Working paper WP04/ 2008/ DE/ UECE.

iii. Akanbi (2014). Government expenditure in Nigeria. Determinants and trends. Mediterranean Journal of social sciences, 5(27)

iv. Appah, E. \& Ateboh-Briggs, P.B(2013). Cointegration of public sector expenditure patterns and growth of Nigeria. Developing country studies, 3(9)

v. Aregbeyen, O. (2006). Cointegration causality and wagner's law: A test for Nigeria. Central Bank of Nigeria Economic and Financial Review, 44(2), 1-17.

vi. $\quad$ Bhatia H.L. (2002). Public Finance. 25th Edition. Vikas Publishing House, PVT Ltd, India.

vii. Bird, R.M.(1971).Wagner's law of expanding state activity. Public Finance/ Finances Publique, 26(2), 1-26.

viii. Buhari, A.L. (1993).ICAN/ Polytechnic Public Finance. Ilorin, University of Ilorin Press.

ix. CBN (2016). Statistical bulletin. www.cenbank.org.

x. Chude, N.P \& Chude, D.I (2013). Impact of government expenditure on economic growth in Nigeria. International Journal of Business and management Review, 1(4),

xi. $\quad 64-71$

xii. Danladi, Akomolafe \& Anyadiegwu (2015). Government expenditure and its implication for economic growth: Evidence from Nigeria. Journal of economic and sustainable Development, 6(18)

xiii. Ditimi, A., Nwosa, P.\& Ajisafe, R.A. (2011). Components of government spending and economic growth in Nigeria: An error correction modeling. Journal of Economic and sustainable development, 2(4).

xiv. Edame, E. (2001). The essentials of public finance and public financial management in Nigeria. Calabar, Wusen Press Ltd.

xv. Edame, G. E \& Akpan, V.E (2013). An empirical analysis of the structure and growth of federal Government expenditure in Nigeria. Journal of Economic and sustainable Development. 4(15).

xvi. Ezirim, B. C.,\& Ofurun (2003). Public expenditure growth and Inflation in developed and developing countries. Nigeria Business and Social Review, 2(1), 75 -94

xvii. Ezirim, C. M., Moughalu \& Elike, U. (2008). Inflation versus public expenditure growth in the US: An empirical investigation. North American Journal of Finance and Banking Research, 2(2).

xviii. Goffman, I. J. (1968). On the empirical testing of Wagner's law: A technical note. Public Finance/ Finance Publique, 23(3), 359-64.

xix. Gupta, S. P. (1967). Public expenditure and economic growth: a time analysis. Public Finance/ Finances Publique, 22(4), 423-61.

xx. Henrekson, M. (1993). Wagner's law: A spurious relationship? Public Finance/ Finances Publique, 48(2), 406-15. 
xxi. Irmen, A. \& Kuehnel, J. (2008). Productive government expenditure and economic growth. Department

Economics, University of Heidelberg. Discussion Paper Series No. 464.

xxii. Retrieved on 6/5/2018 fromwww.awi.uni- heidelberg.de/ with2/ discussion\%20papers/ papers/dp464.pdf

xxiii. Jhingan M.L. (2007). The economics of development and planning (39th ed).Virinda Publications Ltd. New Delhi.

xxiv. Jhingan, M. L. (2004). Macro-Economic Theory (11 ed). Vrinda Publications Ltd. New Delhi.

xxv. Josaphat, P. K. \& Oliver, M. (2000). Government spending and economic growthin Tanzania, 1965-1996. Credit Research Paper.

xxvi. Lindauer, D. L. \& Velenchik, A. D. (1992). Government spending in developing countries: Trends, causes, and consequences. World Bank Observer, 59-78.

xxvii. Maku, O.E. (2009). Does government spending spur economic growth in Nigeria?Munich Personal RePEc Archive. Retrieved on 8/5/2018 from http:// mpra.ub.uni- muenchen.de/ 17941/ MPRA Paper no. 17941.

xxviii. Michas,N.A.(1975). Wagner"s law of public expenditures: what is the appropriate measurement for a valid test. Public Finance/ Finances Publiques, 30(1), 77-84.

xxix. Miftahu, I. \& Rosini, B.(2017). Public sector spending and economic growth in Nigeria: In search of a stable relationship. Asian journal of Arts and Social Sciences, 3(2), 1-19.

xxx. Minea, A. (2008). The role of public spending in the economic growth evolution. Romanian Journal of Economic Forecasting, 2, 99 - 120.

xxxi. Musgrave A. \& Musgrave P.B. (1989). Public finance in theory and practice. New Delhi, Tata McGraw Hill Education Private Limited.

xxxii. $\quad$ Musgrave, R. A. (1969). Fiscal System. New Haven and London, Yale University Press.

xxxiii. Nurudeen, A. \& Usman, A. (2010). Government expenditure and economic growth in Nigeria: A disaggregated analysis. Business and Economics Journal. BEJ-4:01-11.

xxxiv. Ogundipe, A. A. \& Oluiwatobi (2012). Government spending and economic growth in Nigeria: Evidence from disaggregated analysis. Journal of economic and sustainable

xxxv. Development.4(7)

xxxvi. Ogwuru, H.O.R. \& Ewubare, (2009). Exchange rate dynamics and current account balance in Nigeria. Journal of Finance, Banking and Investment. Abia State University Uturu, 3(1), 74:85

xxxvii. Okanta, S.U. (2009). The impact of public education on economic growth in Nigeria (1990-2008): Evidence from bivariate and multivariate regression. Journal of Finance and Economic Research, ABSU, (2)1, 18-34.

xxxviii. Okoro, A.S.(2013). Government spending and economic growth in Nigeria. Global Journal of

xxxix. Management and Business Research Economics and Commerce, 13(5), 21-30. Okpara, G.C.(2002). Public finance: A theoretical and practical survey. Willy Rose Publishers, Abakaliki.

xl. Oziengbe, S.A. (2013). The relative impacts of federal capital and recurrent expenditure and Nigeria's economy. American Journal of Economic. 3(5), 210-22

xli. Peacock, A. \& Wiseman, J. (1979). Approaches to the analysis of government expenditures growth. Public Finance Quarterly, Available: Http:/ / Journals.Sagepub.Com/ Doi/ Pdf/ 10.1177/ 109114217900700101

xlii. Pigou, A.C. (1928). A study in public finance. London: Macmillan.

xliii. Sevitenyi, L.N. (2012). Government expenditure and economic growth in Nigeria: An empirical investigation. The Journal of Economic Analysis. 111(1), 38-45

xliv. Taiwo, M. \& Aboyomi T.(2012). Government expenditure and economic development: Evidence. MPRA paper no.37293.

xlv. Vaish, M.C. (2002). Macro-economic theory (12 ed). New Delhi: Vikas Publishing House.

xlvi. Vedder, R.K. \& Gallaway, L.E. (1998). Government size and economic growth. Ohio Washington, D.C.

xlvii. Wagner, A. (1963). Three extracts on public finance in Musgrave R.A. and Peacock, A. (Eds.): Classic in the theory of public finance. New York, Macmillan. 